\title{
Microsatellite variation in ringed seals (Phoca hispida): genetic structure and history of the Baltic Sea population
}

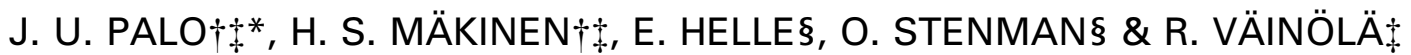 \\ $\dagger$ Department of Ecology and Systematics and $₫$ Finnish Museum of Natural History, POB 17, FIN-00014 University \\ of Helsinki, Finland and §Finnish Game and Fisheries Research Institute, POB 6, FIN-00721 Helsinki, Finland
}

\begin{abstract}
Genetic variability and population structure of Baltic ringed seals and an Arctic reference population were assessed using eight microsatellite loci. Ringed seals colonized the Baltic Sea basin soon after deglaciation 11500 years ago and are supposed to have remained largely isolated from the main Arctic stock since then, $\approx 1000$ generations. In the 1900 s the Baltic population declined rapidly, and is now confined to three distinct breeding areas, with $N<6000$ seals altogether. Microsatellite heterozygosity in ringed seals was higher than that in the closely related, boreal harbour seal and grey seal, for which the markers were initially developed. This is plausibly attributed to an overall greater population (species) size of ringed seals during the Quaternary. Allele frequency differentiation between the Baltic and Arctic ringed seals, conventionally treated as different subspecies, was weak. Assuming complete isolation, the divergence $\left(F_{\mathrm{ST}}=0.023\right)$ would imply a notably high postglacial effective population size, $\approx 20000$ for the Baltic population. The isolation assumption however, seems unrealistic in the light of the data: a coalescent-based simulation approach to the likelihood of alternative demographic histories clearly favoured a scenario with recurrent gene flow to the Baltic, over one of complete isolation (drift only). Within the Baltic Sea, no differentiation was found between the Gulf of Finland and the Gulf of Bothnia breeding areas; the recent population decline and split have not yet affected the inbreeding levels of the disjunct breeding stocks.
\end{abstract}

Keywords: effective population size, gene flow, microsatellite, population differentiation, postglacial isolation, ringed seal.

\section{Introduction}

PCR-based hypervariable DNA-markers, such as microsatellites and mtDNA, have proven particularly useful in population studies of marine mammals, which at least periodically are inaccessible for direct field observations. Most notably, molecular markers have given new information on cetacean biology, including aspects of intraspecies systematics, population history, abundance, migrations, structure of social groups and levels of gene flow; they have also been used for species and individual identification (e.g. Hoelzel, 1998; Palumbi \& Cipriano, 1998; and references therein). DNA markers have also enabled efficient population genetic studies of seals, which previously were largely unassessable due to lack of allozyme variation (e.g. Stanley et al., 1996; Goodman, 1998; Wynen et al., 2000). Microsatellite markers isolated from one seal species are usually widely

\footnotetext{
*Correspondence. E-mail: jukka.palo@helsinki.fi
}

applicable in other pinnipeds also (Gemmell et al., 1997).

Six phocid seal species inhabit North European waters; of these the harbour seal (Phoca vitulina), grey seal (Halichoerus grypus) and ringed seal (Phoca hispida) extend into the Baltic Sea. The three species make a phylogenetically close cluster (Árnason et al., 1993), yet they differ considerably in their population and social structures and migratory patterns (Bonner, 1994). So far, microsatellite assessments of the harbour and grey seal population structures have yielded partly unexpected results, e.g. strong differences between geographically close populations (Allen et al., 1995; Goodman, 1998). We now assess the population genetics of the ringed seal, focusing on questions of the history and structure of the Baltic population, assigned to P. hispida botnica.

Arctic ringed seals could initially colonize the Baltic Sea basin during the deglaciation $\approx 11500$ calendar years ago (the Yoldia Sea stage), and were subsequently temporarily sequestered in the freshwater Ancylus Lake 
stage of the basin. Subsequently, a marine connection between the Baltic and North Sea was re-established and has thereafter remained open (Björck \& Sandgren, 1987; Donner, 1995). However, due to the requirement of firm ice for breeding, it has been supposed that the ringed seal populations of the Arctic and Baltic Sea have remained in effective isolation since the Ancylus stage (Forstén \& Alhonen, 1975). In the 20th century, the formerly large Baltic population crashed due to overhunting and reproductive failures. The estimated hauledout population size in 1996 was around 5500. Breeding is mainly confined to three distinct peripheral areas: the Gulf of Bothnia, the Gulf of Riga and the Gulf of Finland (Härkönen et al., 1998; Fig. 1).

Using heterospecific pinniped microsatellite markers, we address three issues of the genetic variation and history of ringed seals. First, the levels of heterozygosity in the ringed seal and its close relatives are examined in relation to their biology and long-term population histories. Second, we investigate the differentiation between Arctic and Baltic populations. The relative likelihoods of two extreme alternative scenarios of population structure and history (drift only vs. recurrent gene flow) are assessed using a coalescent-based simulation approach (Ciofi et al., 1999), and implications for the status of the Baltic population or subspecies are discussed. Third, we assess the differentiation between separate breeding areas within the Baltic Sea.

\section{Materials and methods}

Altogether 149 Baltic ringed seal individuals from two breeding areas, the Gulf of Finland and the Gulf of Bothnia, were used for the analyses. Thirty-nine ringed seals from Spitsbergen in the Svalbard archipelago made up an Arctic reference sample. The seals had either been found dead in fishing gear, or been killed in ordinary hunt or by the Finnish Game and Fisheries Research Institute for scientific purposes between 1981 and 1997. Tissue samples had been stored at $-20^{\circ} \mathrm{C}$.

DNA from muscle or liver was extracted using a standard SDS-proteinase $\mathrm{K}$ digestion procedure followed by ethanol precipitation (e.g. Bruford et al., 1992). Variation at eight dinucleotide microsatellite loci was assessed. Primers for four loci (SGPV2, -9, -10 and -16) had originally been designed for the harbour seal (Goodman, 1997a), and four others for the grey seal (Allen et al., 1995; Hg4.2, -6.1, -6.3 and -8.10). PCR reactions were performed in a total volume of $20 \mu \mathrm{L}$, with approximately $20 \mathrm{ng}$ of template DNA, $5 \mathrm{pmol}$ of each primer, $0.25 \mathrm{U}$ AmpliTaq DNA polymerase (Perkin-Elmer), 1× PCR buffer II (Perkin-Elmer), $2.5 \mathrm{mM} \mathrm{MgCl}_{2}, 200 \mu \mathrm{M}$ of each nucleotide and $0.5-1$ $\mu \mathrm{Ci} \alpha{ }_{-}{ }^{32} \mathrm{P}$ dCTP $(3000 \mathrm{Ci} / \mathrm{mmol}$, Amersham). The ori-
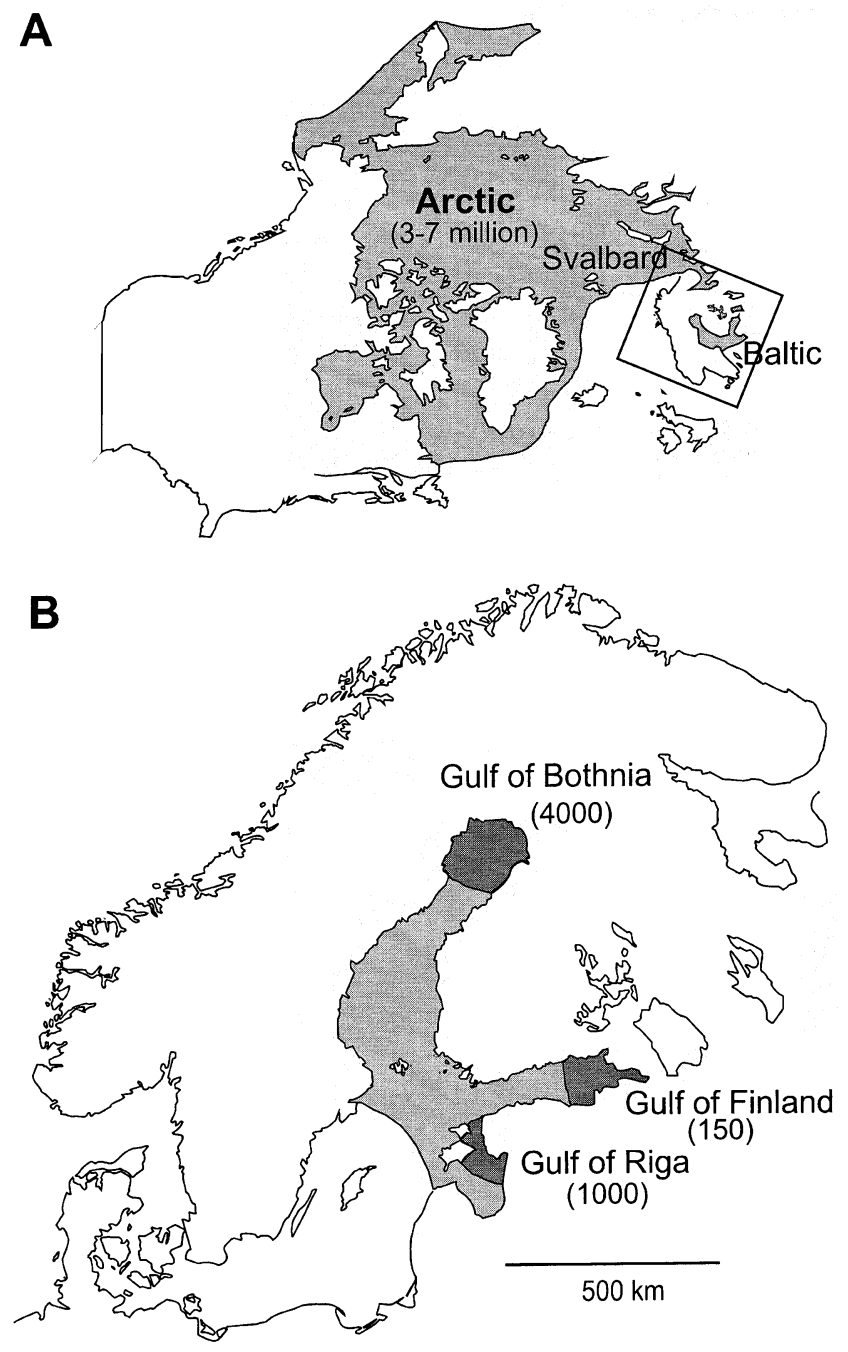

Fig. 1 Distribution and approximate current population sizes of the ringed seal (A) worldwide and (B) in the Baltic Sea (Härkönen et al., 1998). Darker shading in the Baltic shows the three main breeding areas.

ginal PCR cycling profiles of Allen et al. (1995) and Goodman (1997a) were used. PCR products were resolved on $6 \%$ acrylamide gels under denaturing conditions (7 $\mathrm{m}$ urea) and documented by autoradiography. Allele sizes were estimated using a DNA sequence ladder and known genotypes were used as standards across gels.

Tests of allele frequency homogeneity between populations and of Hardy-Weinberg genotypic distribution (against alternative hypothesis of within-population heterozygote deficiency) were performed using exact tests as implemented in GENEPOP 1.2 (Raymond \& Rousset, 1995) and FSTAT (Goudet, 1995). GENEPOP was also used in testing independence of genotype distributions (linkage equilibrium) between pairs of 
loci in each sample. Heterozygote deficit $\left(F_{\text {IS }}\right)$ and allele frequency differentiation between populations $\left(F_{\mathrm{ST}}\right)$ were estimated according to Weir \& Cockerham (1984). Differentiation was also estimated in terms of $R_{\mathrm{ST}}$, which uses information from differences in microsatellite allele size distributions (Slatkin, 1995; Goodman, 1997b).

The standard $F_{\mathrm{ST}}$ estimate may be used to estimate long-term effective population size, assuming complete isolation and equal sizes of the compared populations since their separation from a common ancestral stock, a known number of generations $t$ ago (i.e. similar effects of drift in the Baltic and Svalbard populations, negligible mutation and migration). The expected differentiation for isolated populations is $F_{\mathrm{ST}}=1-\exp \left(-t / 2 N_{\mathrm{e}}\right) \sim t /$ $\left(2 N_{\mathrm{e}}\right)$, and an estimate of long-term $N_{\mathrm{e}}=t /\left(2 F_{\mathrm{ST}}\right)$ for small $F_{\mathrm{ST}}$ (e.g. Hartl \& Clark, 1997).

Using a simulation approach based on coalescent theory, the patterns of allele frequency differentiation were used for further resolution of population history. With this approach, population-wise (unequal) deviations $F_{i}\left(=F_{\mathrm{ST}(i)}\right)$ of the studied populations from the ancestral stock can be estimated, and thus also their individual $N_{\mathrm{e}} \mathrm{s}$ under the isolation model (O'Ryan et al., 1998). Further, the relative likelihoods of alternative scenarios of demographic history were evaluated with the method of Ciofi et al. (1999; implemented in the program 2MoD by M. A. Beaumont), where the complete isolation (drift only) model is contrasted by another extreme model of drift-gene flow equilibrium, i.e. recurrent immigration from a stable base population to maintain the observed level of differences. The method uses a Markov chain Monte Carlo simulation approach with Metropolis-Hastings sampling to explore the set of possible ancestral gene frequencies, alternative models and population structure parameters $\left(F_{i}\right.$, related to $t / N$ and to $N m$ under the alternative models) and their likelihood of producing the observed data. Simulations were performed as in Ciofi et al. (1999); data are presented on the combined results of two independent simulation runs of 200000 iterations each. The proportions of accepted data points representing the gene flow vs. the isolation models are interpreted as the relative likelihoods of these models, and estimates of $F_{i}$ conditional on each model are obtained from the means of the marginal posterior distributions of the simulated data points representing that model. Under the gene flow model, the estimated number of immigrants to the Baltic is obtained from the island model equilibrium as $N m=\left(1-F_{\text {BALTIC }}\right) /\left(4 F_{\text {BALTIC }}\right)$. It is assumed that effects of mutation are negligible: in the gene-flow model, mutation rate $u$ should be much less than gene flow rate $m$, and in the drift-only model much smaller than the reciprocal of $t$, the number of generations since isolation. These assumptions should be met in the current case if $u$ is of the order $10^{-4}$ or less.

\section{Results}

\section{Microsatellite variability and genotypic structure}

The eight microsatellite loci were highly variable in the ringed seal, allele numbers ranging from eight to 17 per locus and averaging 12.4 (Table 1). Of the 99 alleles detected 91 were present in the Svalbard sample and 93 in the Baltic. Six alleles were unique to the Svalbard sample and eight to the Baltic. The expected heterozygosities in the Svalbard and Baltic populations were 0.82 and 0.80 , respectively. Nominally significant heterozygote deficits were recorded at three loci (SGPV16, $\mathrm{Hg} 4.2, \mathrm{Hg} 6.1)$ in the Gulf of Bothnia, and at one locus $(\mathrm{Hg} 8.10)$ in both Arctic and Gulf of Finland populations. No significant departures remained when a sequential Bonferroni procedure (Rice, 1989) was applied to the test results. The overall estimate of $\hat{F}_{\text {IS }}=0.013(95 \%$ bootstrap limits -0.007 to 0.036$)$. Of 84 individual pairwise tests for linkage disequilibrium, only two indicated nonindependence of genotypes at the nominal 0.05 level (Hg6.3 vs. Hg8.10 in both Baltic subsamples).

\section{Population differentiation}

No differentiation was detected between the two Baltic breeding areas at any locus; the overall estimate for $F_{\mathrm{ST}}=0.000$. The Baltic material was therefore pooled for further analyses.

Allele frequency differences between the Baltic and Arctic populations were not large, yet statistically significant at six of the eight loci (Fig. 2). The conventional estimate of overall differentiation (Weir \& Cockerham, 1984) $F_{\mathrm{ST}}=0.017$ (technical $95 \%$ limits from bootstrap 0.007-0.029; range of locus-wise estimates $0.001-0.050)$. Analogous estimates based on the allele size distributions were lower and not significant (overall $R_{\mathrm{ST}}=0.002$ ). Locus-wise estimates of $R_{\mathrm{ST}}$ showed no correlation with corresponding estimates of $F_{\mathrm{ST}}(r=-0.15)$.

The generation interval for the ringed seal was estimated using the age-specific fecundity scheme inferred by Smith (1973) for a Canadian Arctic population. The average female generation interval is 10.5 years; males mature approximately one year later than females. Thus we take 11 years as the overall generation time, and the period since isolation is $t=10900 / 11=990$ generations. Then, assuming equal population sizes and complete isolation (drift only; negligible migration or mutation), the estimated 
Table 1 Sample sizes $(N)$, observed numbers of different alleles $(A)$, expected heterozygosities $\left(H_{\text {exp }}\right)$ and deviations from the HW equilibrium $\left(F_{\text {IS }}\right)$ at eight loci in the three samples of ringed seals

\begin{tabular}{|c|c|c|c|c|c|c|c|c|c|}
\hline & $S G P V 2$ & $S G P V 9$ & SGPV10 & SGPV16 & $\mathrm{Hg} 4.2$ & Hg6.1 & Hg6.3 & $\mathrm{Hg} 8.10$ & Mean \\
\hline \multicolumn{10}{|l|}{ GB } \\
\hline$N$ & 51 & 56 & 54 & 66 & 54 & 61 & 53 & 64 & 57.4 \\
\hline$A$ & 10 & 8 & 14 & 7 & 16 & 15 & 10 & 8 & 11.0 \\
\hline$H_{\text {exp }}$ & 0.76 & 0.64 & 0.90 & 0.80 & 0.80 & 0.88 & 0.89 & 0.68 & 0.80 \\
\hline$F_{\mathrm{IS}}$ & 0.17 & -0.05 & 0.01 & 0.11 & 0.05 & 0.11 & 0.02 & -0.15 & 0.04 \\
\hline \multicolumn{10}{|l|}{ GF } \\
\hline$N$ & 57 & 64 & 70 & 58 & 67 & 68 & 64 & 67 & 64.4 \\
\hline$A$ & 11 & 9 & 14 & 7 & 14 & 15 & 10 & 7 & 10.9 \\
\hline$H_{\exp }$ & 0.79 & 0.63 & 0.87 & 0.78 & 0.89 & 0.87 & 0.89 & 0.71 & 0.80 \\
\hline$F_{\mathrm{IS}}$ & 0.02 & 0.08 & -0.03 & -0.04 & -0.01 & -0.05 & -0.09 & 0.11 & -0.01 \\
\hline \multicolumn{10}{|l|}{ SV } \\
\hline$N$ & 27 & 35 & 36 & 37 & 29 & 33 & 32 & 33 & 32.8 \\
\hline$A$ & 10 & 8 & 15 & 11 & 15 & 15 & 10 & 7 & 11.4 \\
\hline$H_{\text {exp }}$ & 0.88 & 0.58 & 0.92 & 0.81 & 0.93 & 0.90 & 0.88 & 0.65 & 0.82 \\
\hline$F_{\mathrm{IS}}$ & 0.03 & -0.09 & -0.09 & -0.03 & 0.03 & 0.06 & 0.05 & 0.00 & 0.01 \\
\hline \multicolumn{10}{|l|}{ Total } \\
\hline$N$ & 135 & 155 & 160 & 161 & 150 & 162 & 149 & 164 & 154.5 \\
\hline$A$ & 12 & 10 & 15 & 11 & 17 & 16 & 10 & 8 & 12.4 \\
\hline$F_{\text {IS }}$ & 0.01 & -0.01 & -0.03 & 0.02 & 0.02 & 0.03 & -0.02 & 0.02 & 0.01 \\
\hline
\end{tabular}

GB, Gulf of Bothnia; GF, Gulf of Finland; SV, Svalbard.

$F_{\mathrm{ST}}=0.017$ would imply average postglacial $N_{\mathrm{e}}=$

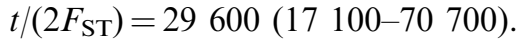

Assessment of the likelihood of alternative scenarios of postglacial demographic history (gene flow vs. isolation) with the simulation approach however, did not support the isolation assumption. The support for the gene flow model was $82 \%$ of the iterations, giving a Bayes factor of $0.82 / 0.18=4.6$ for this scenario; a Bayes factor $>3$ is conventionally referred to as substantial support (Kass \& Raftery, 1995). The drift effects were largely attributable to the Baltic population (Fig. 3). Under the gene-flow model the estimated deviations were $F_{\text {BALTIC }}=0.028, F_{\text {ARCTIC }}=0.007$ (Fig. 3). This level of differentiation would be maintained by an effective immigration of $\mathrm{Nm}=8.7$ individuals per generation into the Baltic. Under the isolation scenario, the estimated population-wise deviations were $F_{\text {BALTIC }}=$ 0.023 and $F_{\text {ARCTIC }}=0.006$, corresponding to $N_{\mathrm{e}}$ estimates of $\approx 21500$ and 82500 , respectively.

\section{Discussion}

\section{Microsatellite diversity and long-term population sizes of phocine seals}

The microsatellite loci studied here showed more variation in ringed seals than in the focal species for which the markers were originally developed. The four har- bour seal loci $(S G P V$-) revealed 48 alleles and an average heterozygosity $H_{\mathrm{e}}=0.78$ in ringed seal, but only seven alleles and $H_{\mathrm{e}}=0.24$ in the harbour seal (Goodman, 1997a, 1998). Two of these loci were actually monomorphic in the harbour seal. Similarly, the four $\mathrm{Hg}$ - loci derived from the grey seal had 51 alleles and $H_{\mathrm{e}}=0.84$ in ringed seals, contrasted with 30 alleles and $H_{\mathrm{e}}=0.76$ in the grey seal (Allen et al., 1995). Considering all microsatellite loci for which data are available with comparable sample sizes, the average allele numbers per locus were 9.7 in the harbour seal (seven loci) and 8.0 in the grey seal (eight loci), contrasted with 12.4 in the ringed seal (eight loci). Also, the expected heterozygosity was higher in the ringed seal $\left(H_{\mathrm{e}}=0.81\right)$ than in the grey seal $\left(H_{\mathrm{e}}=0.77\right)$ or harbour seal $\left(H_{\mathrm{e}}=0.56\right)$. This may seem unexpected, as microsatellite variability tends to be highest in the focal species, an observation generally attributed to 'ascertainment bias' (Ellegren et al., 1995). Allele sizes were similar in the three species at all eight loci.

The three seal species are equally closely related, and thought to have diverged 2.5-3 Myr ago (Árnason et al., 1996). Not much apparent deterioration of microsatellite variability would actually be expected at this level (e.g. Primmer et al., 1996). The interspecific differences in genetic variability are most plausibly attributed to population structure, particularly historical population sizes. The main oceanic population of 
SGPV2

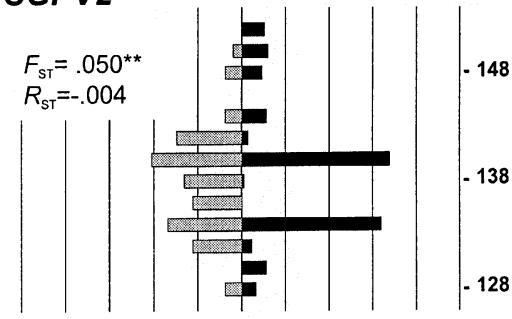

SGPV9

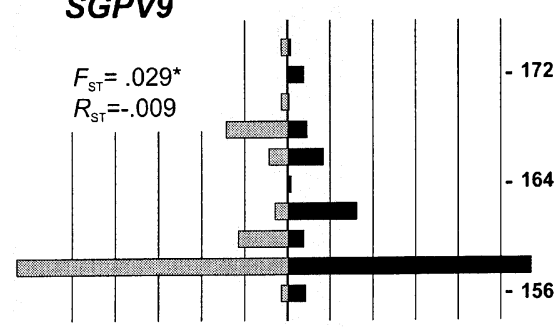

SGPV10

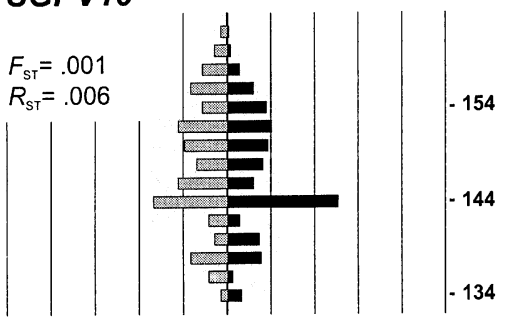

SGPV16

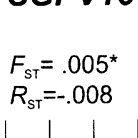

Fig. 2 Observed microsatellite allele frequencies (allele size distributions) and two measures of allele frequency differentiation $\left(F_{\mathrm{ST}}\right.$ and $\left.R_{\mathrm{ST}}\right)$ for the Arctic and the pooled Baltic samples. Sample sizes are given in Table 1.
$H g 4.2$

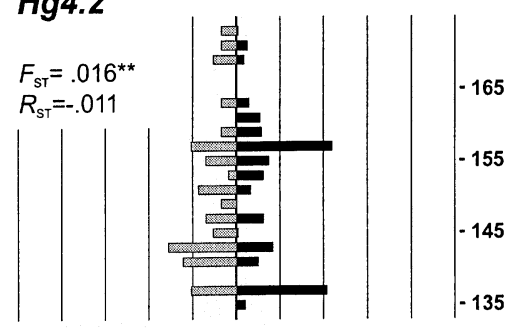

$H g 6.1$

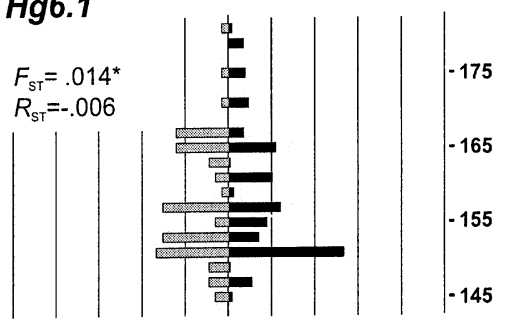

Hg6.3

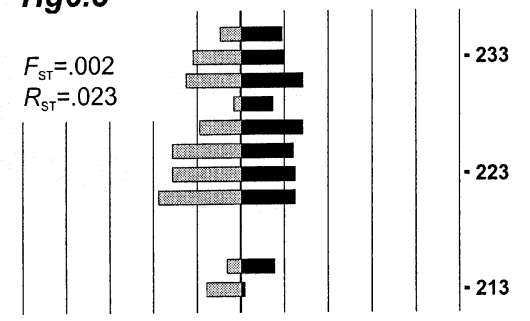

$\mathrm{Hg} 8.10$

$F_{\mathrm{ST}}=.028^{\star *}$

$F_{\mathrm{sT}}=.028^{*}$

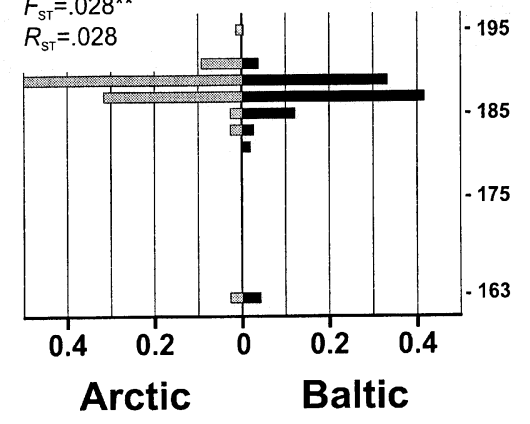

the ringed seal is circumarctic, with a current population size of several million (Reeves, 1998). It breeds on firm ice and could probably have maintained large, connected populations through the Pleistocene glacial cycles. Estimated species sizes are $\approx 550000$ individuals for the harbour seal and 235000 for the grey seal (Bonner, 1994). Distinct genetic subdivision of the harbour seal has been documented both on circumboreal and regional scales (Stanley et al., 1996; Goodman, 1998), whereas in the ringed seal the main population is probably less structured (little mtDNA differentiation across the Arctic; Palo et al. unpublished data).
Supposing that the current level of microsatellite variation $H_{\mathrm{e}}$ in each species represents a long-term mutation-drift equilibrium under the stepwise mutation model (SMM), and that mutation rates are similar between the species, the relative historical sizes of the species may be estimated from $N_{\mathrm{e}}=\left((1-H)^{-2}-1\right) / 8 \mu$ (e.g. Nei, 1987). From the relative heterozygosities in the three species, this would suggest that the ringed seal long-term $N_{\mathrm{e}}$ was 1.5 times that of the grey seal, and about 6.5 times that of harbour seal. This seems reasonable, particularly as the harbour and grey seal estimates refer to the European populations only. The estimated numbers depend on mutation rate; assuming

(c) The Genetics Society of Great Britain, Heredity, 86, 609-617. 


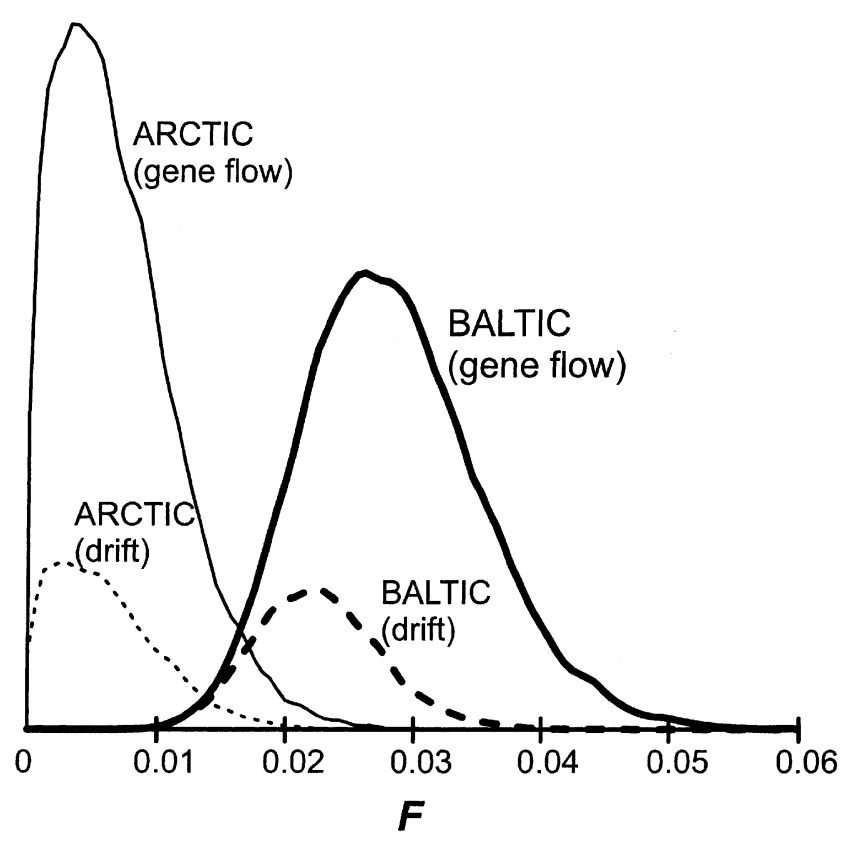

Fig. 3 Posterior marginal distributions of $F_{\mathrm{ST}}$ for the Arctic and Baltic ringed seal populations from the simulations, conditional on the alternative demographic models. The relative likelihood of a model is proportional to the area under the respective curve.

$\mu=10^{-5}$, the implied ringed seal (species) $N_{\mathrm{e}} \approx 330000$; with $\mu=10^{-4}, N_{\mathrm{e}} \approx 33000$.

\section{History and status of the Baltic ringed seal Phoca hispida botnica}

Information on early history of Baltic seals is based on the geological record and on subfossil finds (Forstén \& Alhonen, 1975; Ukkonen, 1993; Donner, 1995). With late-glacial ice retreat, Arctic ringed seals first gained access to the Baltic basin $\approx 11500$ years ago through a strait across central Sweden. Although the marine connection was soon closed due to land uplift, subfossil finds (Ukkonen, 1993) confirm the survival of ringed seals in the ensuing freshwater Ancylus Lake phase of the Baltic $(\approx 10900-9500$ years ago). After the establishment of a final marine connection through the Danish straits, warmer climates probably restricted suitable breeding habitats to northern parts of the Atlantic, and possibly of the Baltic basin as well. Therefore it has been thought that the Baltic and Arctic ringed seals, breeding $\approx 2000 \mathrm{~km}$ apart, have remained isolated since the Ancylus time (Forstén \& Alhonen, 1975).

The overall microsatellite differentiation between the Baltic and Arctic seals was notably weak. Most of the difference could be attributed to drift in the Baltic population $\left(F_{\mathrm{ST}}=0.023\right.$; Fig. 3$)$. Under the isolation assumption this would be compatible with a long-term $N_{\mathrm{e}}$ of the order of 20000 since the assumed colonization some 1000 generations ago.

However, assessment of two alternative models of population history provided strong evidence against the conventional view of long-term isolation. The pattern of allele frequency differentiation suggests a fivefold likelihood for an alternative model of gene-flow drift balance, i.e. recurrent immigration into the Baltic to maintain the relative homogeneity. The estimated rate would be nine effective immigrants into the Baltic per generation - or one per year on average, regardless of the magnitude of $N_{\mathrm{e}}$. This exchange rate may not seem unreasonable, if $N_{\mathrm{e}}$ anyway would have been in some thousands and the relative rate $m$ thus of the order $10^{-3}$ (rather than $10^{-2}$ ). The isolation model, implying a higher $N_{\mathrm{e}}$, would also seem unlikely in a comparative framework. The ringed seal differentiation is lower than that between populations of much more abundant marine invertebrates with similar distributions and 'relict' isolation histories (Pontoporeia femorata, Mysis mixta; Väinölä \& Varvio, 1989; Väinölä, 1992). It is not greater than the differentiation between Baltic and Atlantic populations of some vertebrates (cod Gadus morhua, porpoise Phocoena phocoena), which still have relatively connected ranges (Mork et al., 1985; Andersen et al., 1997). In addition, observations of stray seals (Kapel et al., 1998) and subfossil remains from southern Scandinavia dated to the warm Litorina time (c. 4000 years ago) point to the possibility of genetic exchange (Jonsson, 1995).

The Baltic ringed seal has been treated as a subspecies Phoca hispida botnica Gmelin 1785, distinct from the nominate $P$. h. hispida in the Arctic. The grounds for the distinction are vague however, particularly in comparison with the two landlocked subspecies in lakes Saimaa (P. h. saimensis) and Ladoga (P. h. ladogensis) - both descendants of Baltic seals. The isolation times of the three populations are similar. The Baltic seal only slightly deviates from the nominate taxon in body size, whereas the lacustrine subspecies clearly differ also in skull morphology, pelage colour and behaviour (Hyvärinen \& Nieminen, 1990; Amano et al., 1999). Subspecies status should be based on morphological or adaptive multitrait divergence along with an interpretation of the population structure and history. The distinction of $P$. h. botnica seems to have chiefly relied on its inferred long-term isolation history and its relict status in a deviating environment. The relative homogeneity observed here, and the inferred history, provide no additional support for the distinction. On the other hand, it should be noted that the (low) level of immigration inferred would not be able to prevent the 
evolution of adaptive differences in large populations, or to retard a demographic decline; it should not affect the treatment of the Baltic ringed seals as an independent and biologically unique entity.

\section{Population structure and conservation of Baltic ringed seals}

Estimates based on bounty statistics and life history features suggest that there still were 150 000-250000 ringed seals in the Baltic 100 years ago (Kokko et al., 1999). Thereafter the population declined, initially due to hunting. Since the 1960 s, female sterility caused by pathological uterine changes probably related to environmental toxins has also contributed to the decrease (Helle \& Stenman, 1980). The decline has been accompanied by splitting into three main breeding ranges, determined by ice conditions. The hauling-out population estimates in 1996 were 4000, 1400 and 150 for the Gulf of Bothnia, the Gulf of Riga and the Gulf of Finland, respectively (Härkönen et al., 1998).

We found no differentiation between seals from the Gulf of Bothnia and the Gulf of Finland, separated by $\sim 700 \mathrm{~km}$. The homogeneity probably also applies to the Gulf of Riga seals, which are better connected to the Gulf of Bothnia than are the Gulf of Finland seals. The data imply an effectively panmictic Baltic population in the past. The recent decline and fragmentation have not yet had any detectable effect on the genetic structure. The genetic homogeneity of the ringed seal is in sharp contrast with the harbour seal, where colonies less than $200 \mathrm{~km}$ apart show strong differentiation $\left(F_{\mathrm{ST}}=0.06\right.$, Goodman, 1998). The observation is in line with the different histories and the social and dispersal characteristics of the species.

The putative adverse effects of the fragmentation would mainly concern the Gulf of Finland, where the current $N_{\mathrm{e}}$ is well below 50 , which is often cited as a minimum genetically safe population size (Franklin, 1980). Technically, if a population remains at this size in isolation, its inbreeding level and differentiation will increase at a rate $\Delta F=1 /\left(2 N_{\mathrm{e}}\right), \approx 1-3 \%$ per generation, and so soon exceed, e.g. the difference between the Arctic and Baltic populations. Yet, the potential genetic threats for the Gulf of Finland population may not be of primary concern. First, the inferred abundant historical gene flow suggests that the isolation would not be complete even now, at the reduced densities. From the technical $95 \%$ bootstrap upper bound of $F_{\mathrm{ST}}=0.001$, minimum gene flow in the past would have been of the order $N m=250$ per generation. If the same proportion of individuals $(m)$ still moves, the Gulf of Finland would today, after a 50 -fold reduction in the Baltic population size, still receive 5-10 individuals each generation. In a stable situation this would limit the divergence/inbreeding at $F<0.05$. Also, the homogeneity suggests that the population is unlikely to harbour any unique (threatened) locally adaptive features. At the moment, demographic and environmental threats to the Gulf of Finland subpopulation are clearly the critical ones, and measures on these issues should be taken much sooner than the time scale implied in the genetic effects.

\section{Conclusion}

The level of nuclear genetic variation in the principally Arctic ringed seal is higher than that in the closely related Boreal harbour seal and grey seal. This agrees with the current population (species) sizes of the taxa, and with their plausible population histories through the Pleistocene glaciation cycles. Largely for climatic considerations, the Baltic ringed seal population has been regarded as having remained effectively isolated from the Arctic population since the early postglacial. However, the pattern of microsatellite allele frequency differentiation suggests recurrent influx of immigrants into the Baltic; the observed low divergence is not due to a continuously large effective size alone.

During the last century, the Baltic ringed seal population declined from $\approx 200000$ individuals to $\approx 5500$, divided among three distinct breeding areas; the smallest, Gulf of Finland subpopulation comprises 150 seals only. No genetic subdivision was, however, seen yet in recent Baltic samples; the main threats to the isolate in the near future will be demographic and environmental rather than genetic.

\section{Acknowledgements}

We thank the two anonymous referees and the editor for valuable suggestions and Drs Jodie Painter and Craig Primmer for commenting on the manuscript. The work was supported by grants from the Academy of Finland, part of the Finnish Biodiversity Research Programme FIBRE.

\section{References}

AlleN, P. J., AMOS, W., POMERoY, P. P. AND TWISS, S. D. 1995. Microsatellite variation in grey seals (Halichoerus grypus) shows evidence of genetic differentiation between two British breeding colonies. Mol. Ecol., 4, 653-662.

AMANO, M., HAYANO, A. AND MIYAZAKI, N. 1999. Geographic variation in the skulls of ringed seal, Phoca hispida. In: Miyazaki, N. (ed.) Biodiversity, Phylogeny and Environment in Lake Baikal, pp. 113-128. P. Otsuchi Marine Research Centre, University of Tokyo, Iwate. 
ANDERSEN, L. W., HOLM, L. E., SIEGISMUND, H. R., CLAUSEN, B. ET $A L$. 1997. A combined DNA-microsatellite and isozyme analysis of the population structure of the harbour porpoise in Danish waters and West Greenland. Heredity, 78, 270-276.

ÁRNASON, Ú., GULlBERG, A., JOHNSSON, E. AND LEDJE, C. 1993. The nucleotide sequence of the mitochondrial DNA molecule of the grey seal, Halichoerus grypus, and a comparison with mitochondrial sequences of other true seals. J. Mol Evol., 37, 323-330.

Árnason, Ú., XU, X., GUllberG, A. AND Graur, D. 1996. The 'Phoca Standard': an external molecular reference for calibrating recent evolutionary divergences. J. Mol. Evol., 43, 41-45.

BJÖRCK, S. AND SANDGREN, P. 1987. A magnetostratigraphic comparison between ${ }^{14} \mathrm{C}$ years and varve years during the late Weichselian, indicating significant differences between the time-scales. J. Quaternary Sci., 2, 133-140.

BONNER, N. 1994. Seals and Sea Lions (of the World). Blandford Press, London.

BRUFORD, M. W., HANOTTE, O., BROOKFIELD, J. F. Y. AND BURKE, T. 1992. Single-locus and multilocus DNA fingerprinting. In: Hoelzel, A. R. (ed.) Molecular Genetic Analysis of Populations. A Practical Approach, pp. 225-269. Oxford University Press, Oxford.

CIOFI, C., BEAUMONT, M. A., SWINGLAND, I. R. AND BRUFORD, M. W. 1999. Genetic divergence and units for conservation in the Komodo dragon Varanus komodoensis. Proc. R. Soc. B., 266, 2269-2274.

DONNER, J. 1995. The Quaternary History of Scandinavia. Cambridge University Press, Cambridge.

ELlEGREN, H., PRIMMER, C. R. AND SHELDON, B. C. 1995. Microsatellite 'evolution': directionality or bias? Nature Genet., 11, 360-362.

FORSTÉN, A. AND ALHONEN, P. 1975. The subfossil seals of Finland and their relation to the history of the Baltic Sea. Boreas, 4, 10-22.

FRANKLIN, I. R. 1980. Evolutionary changes in small populations. In: Soulé, M. E. and Wilcox, B. A. (eds) Conservation Biology, pp. 135-149. Sinauer Associates, Sunderland, MA.

GEMMELl, N. J., ALLEN, P. J., GOODMAN, S. J. AND REED, J. Z. 1997. Interspecific microsatellite markers for the study of pinniped populations. Mol. Ecol., 6, 661-666.

GoODmAN, s. J. 1997a. Dinucleotide repeat polymorphisms at seven anonymous microsatellite loci cloned from the European harbour seal (Phoca vitulina vitulina). Anim. Genet., 28, $310-311$

GOODMAN, S. J. 1997b. Rst Calc: a collection of computer programs for calculating estimates of genetic differentiation from microsatellite data and determining their significance. Mol. Ecol., 6, 881-885.

Goodman, s. J. 1998. Patterns of extensive genetic differentiation and variation among European Harbor seals (Phoca vitulina vitulina) revealed using microsatellite DNA polymorphisms. Mol. Biol. Evol., 15, 104-118.

GOUDET, J. 1995. FSTAT, version 1.2: a computer program to calculate $F$-statistics. J. Hered., 86, 485-486.
HÄRKÖNEN, T., STENMAN, O., IÜSSI, M., IÜSSI, I. ET $A L .1998$. Population size and distribution of the Baltic ringed seal (Phoca hispida botnica). In: Heide-Jørgensen, M. P. and Lydersen, C. (eds) Ringed Seals in the North Atlantic. NAMMCO Scientific Publications, vol. 1, pp. 9-45. North Atlantic Marine Mammal Commission, Tromsø.

HARTL, D. L. AND ClARK, A. G. 1997. Principles of Population Genetics, 3rd edn. Sinauer Associates, Sunderland, MA.

HELLE, E. AND STENMAN, O. 1980. Lowered reproductive capacity in female ringed seals (Pusa hispida) in the Bothnian Bay, northern Baltic Sea, with special reference to uterine occlusions. Ann. Zool. Fenn., 17, 147-158.

HOELZEL, A. R. 1998. Genetic structure of cetacean populations in sympatry, parapatry, and mixed assemblages: Implications for conservation policy. J. Hered., 89, 451-458.

HYVÄRINEN, H. AND NIEMINEN, M. 1990. Differentiation of the ringed seal in the Baltic Sea, Lake Ladoga and Lake Saimaa. Finnish Game Res., 47, 21-27.

JONSSON, L. 1995. Vertebrate fauna during the Mesolithic on the Swedish west coast. In: Fisher, A. (ed.) Man and Sea in the Mesolithic, pp. 147-157. The Short Run Press, Oxford.

KAPEL, F. O., CHRISTIANSEN, J., HEIDE-JøRGENSEN, M. P., HÄRKÖNEN, T. ET AL. 1998. Netting and conventional tagging used to study movements of ringed seals (Phoca hispida) in Greenland. In: Heide-Jørgensen, M. P. and Lydersen, C. (eds) Ringed Seals in the North Atlantic. NAMMCO Scientific Publications, vol. 1, pp. 9-45. North Atlantic Marine Mammal Commission, Tromsø.

KASS, R. E. AND RAfTery, A. E. 1995. Bayes factors. J. Am. Stat Assoc., 90, 773-795.

KOKKO, H., HELLE, E., LINDSTRÖM, J., RANTA, E. ET AL. 1999. Backcasting population sizes of ringed and grey seals in the Baltic and Lake Saimaa during the 20th century. Ann. Zool. Fenn., 36, 65-73.

MORK, J., RYMAN, N., STÅHL, G., UTTER, F. ET AL. 1985. Genetic variation in the Atlantic cod (Gadus morhua) throughout its range. Can. J. Fish. Aquat. Sci., 42, 1580-1587.

NEI, M. 1987. Molecular Evolutionary Genetics. Columbia University Press, New York.

O'RYAN, C., HARLEY, E. H., BRUfORD, M. W., BEAUMONT, M. A. ET AL. 1998. Microsatellite analysis of genetic diversity within fragmented South African buffalo populations. Anim. Conserv., 1, 85-94.

PALUMBI, S. R. AND CIPRIANO, F. 1998. Species identification using genetic tools: The value of nuclear and mitochondrial gene sequences in whale conservation. J. Hered., 89, 459-464.

PRIMMER, C. R., MØLleR, A. P. AND EllegreN, H. 1996. A wide range survey of cross-species microsatellite amplification in birds. Mol. Ecol., 5, 365-378.

RAYMOND, M. AND ROUSSET, F. 1995. GENEPOP (version 1.2): population genetics software for exact tests and ecumenicism. J. Hered., 86, 248-249.

REEVES, R. R. 1998. Distribution, abundance and biology of ringed seals (Phoca hispida): an overview. In: HeideJørgensen, M. P. and Lydersen, C. (eds) Ringed Seals in the North Atlantic. NAMMCO Scientific Publications, vol. 1, pp. 9-45. North Atlantic Marine Mammal Commission, Tromsø. 
RICE, W. R. 1989. Analyzing tables of statistical tests. Evolution, 43, 223-225.

SLATKIN, M. 1995. A measure of population subdivision based on microsatellite allele frequencies. Genetics, 139, 457-462.

SMITH, T. G. 1973. Population dynamics of the ringed seal in the Canadian Eastern Arctic. Bull. Fish. Res. Board Can., 181, $1-55$.

STANLEY, H. F., CASEY, S., CARNAHAN, J. M., GOODMAN, S. ET AL. 1996. Worldwide patterns of mitochondrial DNA differentiation in the harbor seal (Phoca vitulina). Mol. Biol. Evol., 13, 368-382.

UKKonen, P. 1993. The post-glacial history of the Finnish mammalian fauna. Ann. Zool. Fenn., 30, 249-263.
VÄINÖLÄ, R. 1992. Evolutionary genetics of marine Mysis spp. (Crustacea: Mysidacea). Mar. Biol., 114, 539-550.

VÄINÖLÄ, R. AND VARVIO, S.-L. 1989. Molecular divergence and evolutionary relationships in Pontoporeia (Crustacea: Amphipoda). Can. J. Fish. Aquat. Sci., 46, 1705-1713.

WEIR, B. S. AND COCKERHAM, C. C. 1984 . Estimating $F$-statistics for the analysis of population structure. Evolution, 38, 1358-1370.

WYNEN, L. P., GOLDSWORThy, S. D., GUINET, C., BESTER, M. N. ET AL. 2000. Postsealing genetic variation and population structure of two species of fur seal (Arctocephalus gazella and A. tropicalis). Mol. Ecol., 9, 283-292. 